\title{
Production and evaluation of biodegraded feather meal using immobilised and crude enzyme from Bacillus subtilis on broiler chickens
}

\section{Isaac Oluseun Adejumo1 ${ }^{1}$, Charles Oluwaseun Adetunji ${ }^{2,3}$}

${ }^{1}$ Animal Nutrition. Food Security and Food Safety Laboratory. Department of Animal Science. Federal University Gashua. Nigeria. Email: smogisaac@gmail.com.

${ }^{2}$ Applied Microbiology. Biotechnology and Nanotechnology Laboratory. Department of Biological Sciences. Landmark University. Omu-Aran. Nigeria.

${ }^{3}$ Jawaharlal Nehru University. School of Life Sciences. Laboratory of Genetic Manipulation for Stress Alleviation and Value Addition in Plants. New Delhi110067. India.

\begin{abstract}
The management of solid wastes has been a major concern to many cities of the world due to daily increasing ruralurban migration and globalization. Due to a greater consumption of poultry meat, the disposal of feather wastes has contributed to the daily increasing environmental pollution. Agricultural wastes (such as poultry feathers) are disposed by burning, which consequently constitute environmental pollution and their chemical or mechanical conversion into animal feed normally leads to minimization of amino acids. The application of biotechnology through the utilisation of enzymes is considered an easy and inexpensive means of producing valuable products from poultry feather wastes. Bacillus subtilis was isolated from a dumping site and the plates were incubated on nutrient agar. The treatments containing $200 \mathrm{~mL}$ each of crude enzyme, immobilized enzyme and sterilized water were added to the bioreactor for biodegradation of chicken feathers. After hydrolysis, the feathers were dried and the products labelled microbial biodegraded feather meal. The effect of temperature, keratinolytic activity and the influence of the immobilised and crude enzyme-degraded feather meal on broiler chickens were assessed. The optimal activity and biodegradative potential of the keratinolytic enzyme was observed as $45^{\circ} \mathrm{C}$ and $48 \mathrm{~h}$ after fermentation, respectively. The weight gain of the birds fed immobilised enzyme-degraded feather meal-based diet compared with the control. The enzymedegraded feather meal is safe for inclusion in broilers' diet and slight feeding manipulations could improve their performance.
\end{abstract}

Keywords: Bacillus subtilis; Biotechnology; Feather wastes; Keratinase.
Received

June 30, 2018

Accepted

August 12, 2018

Released

August 31, 2018

Full Text Article

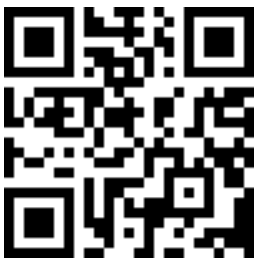

ORCID

(1) 0000-0003-0994-5935

Isaac Oluseun

Adejumo

(D) 0000-0003-3524-6441

Charles Oluwaseun Adetunji 


\section{Introduction}

The number of slaughtered animals has been steadily increasing when compared with animal production growth. This increase in slaughtered animals has also resulted in generation of large quantities of animal wastes (Caires et al., 2010). The management of solid wastes has been a major concern to many cities of the world due to daily increasing rural-urban migration and globalization. Due to a greater consumption of poultry meat, the disposal of feather wastes has contributed to the daily increasing environmental pollution (Okareh et al., 2015). In Nigeria, it has been discovered that the major cities like Lagos and Ibadan generate nearly $0.5 \mathrm{~kg}$ waste/capita/day whereas the national average was $0.45 \mathrm{~kg}$ waste/capita/day (Sridhar, 2001).

It has been noted further that these wastes after being subjected to treatment could be used as potential feedstuff in feeding broiler chickens, thereby reducing the costs of production, especially feed costs, which could account for about $70 \%$ of the total cost of production in raising monogastric animals, such as chickens. Among the most widely used animal by products in feeding broiler chickens are meat meal, bone meal, poultry offal, blood meal, and feather meal, which are known to contain high protein levels and may therefore partially replace conventional protein source in feeding broiler chickens, such as soybean meal. Bellaver (2001) has observed that the growth performance of broiler chickens may vary when fed animal by products, depending on the type and quality of raw material used, processing technique, processing temperature, use of antioxidants for quality maintenance, contamination by pathogenic microorganisms, high polyamine content, amino acid imbalance, nutrient content and digestibility as well as storage conditions.
Poultry feathers are regarded as protein-rich waste products produced from poultry processing industries. Feathers are made up of about 90\% protein and are rich in amino acids such as arginine, cystine and threonine These wastes may usually result in environmental pollution in some places across the globe when allowed to accumulate or burnt indiscriminately (Gupta and Ramnani, 2006; Brandelli, 2008). However, the possibility of degrading the feather wastes into feather meal as feed ingredient for livestock, organic fertilizers and feed supplements has also been documented (Coward-Kelly et al., 2006; Brandelli et al., 2010). Owing to the keratin content of the feather wastes which is usually not easily degraded, hydrothermal processing under high pressure seems to be the most widely used treatment method, which however usually leads to the impairment of important amino acids such as lysine, tyrosine, methionine and tryptophan, as well as resulting in poor digestibility and low nutritional content (Papadopolous et al., 1986; Wang and Parson, 1997). This limitation of thermal processing coupled with high pressure has necessitated the need for the adoption of microbial degradation, giving more rooms daily for the examination of novel and important microbes for efficient degradation of feather wastes into feather meal for feeding livestock.

Poverty, high price of food and feed ingredients, lack of adequate infrastructure as well as food wastage are some of the important factors affecting food security in Africa (Metu et al., 2016). Conventional protein and the energy involved in their production have contributed to the high price of animal feed which consequently lead to high price of the animal at the end of production. Hence, it becomes necessary to source for an alternative economical protein sources for animal production most especially from the poultry wastes which are abundantly available in 
Nigeria (Adetunji and Adejumo 2017). This will go a long way, in the prevention of environmental pollution arising from the disposal of poultry feather wastes and their conversion into animal feeds (Khardenavis et al., 2009; Adejumo et al., 2016; Călin et al., 2017).

Presently, poultry feather wastes are disposed by burning, which consequently constitute to environmental pollution or their conversion into animal feed by mechanical, heat and chemical hydrolysis which normally leads to minimization of useful essential amino acids (Khardenavis et al., 2009). However, the application of biotechnology through the utilisation of enzymes like keratinase has been considered an easy and inexpensive means of producing valuable products from poultry feather wastes (Călin et al., 2017). Keratinase are proteolytic enzymes with degrading ability for keratin-containing substrates, usually produced through submerged and solidstate fermentation from fungal species, actinomycetes and bacterial most especially from Bacillus substilis (Călin et al., 2017; Gopinath et al., 2015; Gröhs et al., 2016; Verma et al., 2016).

The field of microbial biotechnology offers many potentials to the application of immobilization of enzyme which has a lot of benefits when compared to the use of crude enzymes in various industrial processes. These include the reutilization of the enzymes, high productivities, reduced in the cost of producing another enzyme, reduction in the downstream processing (Mariotti et al., 2008, Franssen et al., 2017). Bacillus are the most commonly enquired keratinolytic bacteria. Among the frequently used are Bacillus licheniformis, Bacillus cereus, Bacillus subtilis, Bacillus megaterium, Bacillus polymyxa, Bacillus pumilus, Bacillus halodurans and Bacillus polyfermenticus (Forgacs et al., 2001; Huang et al., 2003; Laba and Rodziewicz, 2010; Prakash et al., 2010; Łaba and Szczekała, 2013; Dong et al., 2017; Adetunji and Adejumo, 2018).
This study aimed to investigate the influence of keratinase and the immobilised keratinase from Bacillus subtills in the degradation of feathers and to investigate the effect of the degraded feather meal in in-vivo trial on broiler chickens.

\section{Materials and methods}

\section{Production, immobilisation of keratinase and assessment of keratinolytic activity from Bacillus subtilis}

The Bacillus subtilis (LMU B01) used was isolated from the feather dumping site of Landmark University Commercial Farm. Incubation of the plates was done on nutrient agar at $37{ }^{\circ} \mathrm{C}$ for $48 \mathrm{~h}$ and stored at $4{ }^{\circ} \mathrm{C}$ in the refrigerator. Three different treatments, each of which contained $200 \mathrm{~mL}$ crude enzyme, immobilized enzyme and sterilized water were added to the bioreactor for biodegradation of chicken feathers. The feathers were dried in the oven at $45^{\circ} \mathrm{C}$ for 2 days after hydrolysis and powdered to a particle size of $1 \mathrm{~mm}$ (Adetunji et al., 2012). The obtained strain (LMU B01) was incubated at $37^{\circ} \mathrm{C}$ for $48 \mathrm{~h}$ after which pure culture was transferred into the inoculum medium $(0.2 \%$ yeast extract at $\mathrm{pH} 7.5$ and $1 \%$ sterilized feather meal). The method adopted for the production and immobilisation of keratinase was earlier reported by Adetunji and Adejumo (2018), while the assessment of biodegradation of keratinolytic activity from Bacillus subtilis followed the procedure reported by Chaturvedi et al. (2014).

\section{Experimental design, management of animals and data collection}

The feeding trial and experimental protocol was carried out in accordance with the Principles of Laboratory Animal Care (NIH publication No. 85-23, revised 1985) and as approved by the Department of Animal 
Science, Federal University Gashua, Animal Ethics Committee. The feeding trial lasted for 21 days. Fourteen-day-old mixed sexed broiler chicks (Arbor Acre strain) chicks. The 144 chicks were grouped into 4 treatments according to weight in a completely randomised design. The treatments contained the control group (corn-so diet). 2.5\% each of commercial feather meal (procured from Agro Bar-Magen Feed Additives, Israel), immobilised enzyme-degraded feather meal and crude enzymedegraded feather meal replaced soybean in treatments 2, 3 and 4, respectively. Each treatment had six replicates with six birds each. Growth performance, haematology, histology of intestines and organ-to-part ratio were investigated. Feed intake (FI) was obtained by finding the difference between the amount of given feed/week and the left-over. The body weight (BW) of each bird was taken at the beginning of the experiment, after which the body weights for each bird were measured every week. The body weight gain (BWG) and feed intake (FI) of the chicks was recorded weekly from which the feed conversion ratio (FCR) was obtained. The experimental diet composition of each group was similar (Table 1).

Table 1. Gross nutrient composition of experimental diets.

\begin{tabular}{|l|c|c|c|c|}
\hline \multicolumn{1}{|c|}{$\begin{array}{c}\text { Feed ingredient } \\
\text { (g/kg) }\end{array}$} & Control diet & $\begin{array}{c}\text { Commercial } \\
\text { feather } \\
\text { meal-based } \\
\text { diet }\end{array}$ & $\begin{array}{c}\text { Crude } \\
\text { enzyme- } \\
\text { degraded } \\
\text { feather meal- } \\
\text { based diet }\end{array}$ & $\begin{array}{c}\text { Immobilised } \\
\text { enzyme-degraded } \\
\text { feather meal- } \\
\text { based diet }\end{array}$ \\
\hline Yellow maize & 60.00 & 60.00 & 60.00 & 60.00 \\
\hline Soybean meal & 28.50 & 26.00 & 26.00 & 26.00 \\
\hline Palm oil & 1.50 & 1.50 & 1.50 & 1.50 \\
\hline Wheat bran & 6.00 & 6.00 & 6.00 & 6.00 \\
\hline Feather meal & 0.00 & 6.00 & 6.00 & 6.00 \\
\hline Premix* & 0.25 & 0.25 & 0.25 & 0.25 \\
\hline Dl-methionine & 0.20 & 0.20 & 0.20 & 0.20 \\
\hline Limestone & 1.50 & 1.50 & 1.50 & 1.50 \\
\hline Di-calcium phosphate & 1.85 & 1.85 & 1.85 & 1.85 \\
\hline Sodium chloride & 0.20 & 0.20 & 0.20 & 0.20 \\
\hline Nutrient analysis & \multicolumn{5}{|l|}{} & & 19.51 \\
\hline Protein & 18.67 & 19.47 & 19.49 & 2912.85 \\
\hline ME (Kcal/kg) & 2950.35 & 2912.85 & 2912.85 & 4.03 \\
\hline Fibre & 4.13 & 4.03 & 4.03 & 3.91 \\
\hline Fat & 3.89 & 3.86 & 3.89 & 0.70 \\
\hline Lysine & 0.75 & 0.70 & 0.70 & 0.45 \\
\hline Methionine & 0.51 & 0.46 & 0.45 & 1.02 \\
\hline Calcium & 1.02 & 1.02 & 1.02 & 0.61 \\
\hline Phosphorus & 0.61 & 0.61 & 0.61 & \\
\hline
\end{tabular}

*2.5 kg contains 8,000,000 i.u. vitamin A, 1,600,000 i.u. vitamin D3, 15,000 i.u. vitamin E, 2,000 mg vitamin $\mathrm{K}, 3,000 \mathrm{mg}$ vitamin B2, $20 \mathrm{~g}$ vitamin C, 20,000 mg niacin, 6,000 $\mathrm{mg}$ pantothenic acid, 1,500 $\mathrm{mg}$ vitamin B6, 10,000 mg vitamin B12, $500 \mathrm{mg}$ folic acid, $400 \mathrm{mg}$ biotin, 150,000 mg choline chloride, $100 \mathrm{mg}$ cobalt, $600 \mathrm{mg}$ copper, 10,000 mg iodine, 20,000 mg iron, 90,000 mg manganese, $100 \mathrm{mg}$ selenium, $20,000 \mathrm{mg}$ zinc, $1,300 \mathrm{mg}$ antioxidant. 
The intestines of representative sample birds were excised separately according to treatment for histological study of the small intestines after the birds have been euthanised, fixed in 10\% formalin solution and the tissues were cut into small about $4 \mathrm{~mm}$ thick and passed through various reagents for dehydration. The tissues were eventually transferred into wax baths for impregnation/infiltration for $12 \mathrm{~h}$. The tissues were floated on water bath (Raymond lamb), picked using clean slides and the slides were dried on a hotplate (Raymond lamb), set at $60^{\circ} \mathrm{C}$ for $1 \mathrm{~h}$. The slides were stained with haematoxylin and eosin (Galighor and Koziff, 1976; Avwioro, 2010). Birds from each replicate were euthanised, viscera and organs were weighed and proportion to live weight was calculated. The procedure by Schalm et al. (1975) and Aiello (1998) was adopted for blood analysis.

\section{Statistical analysis}

The obtained were analyzed by one-way analysis of variance (ANOVA) using the software, Statistical Package for Social Sciences (SPSS) (Version 21 Armonk, NY: IBM Corp.) and the means were separated using Duncan's multiple range test (Duncan, 1955) of the same software. Values were expressed as mean \pm standard error of mean (SEM). The level of statistical significance was $\mathrm{P}<0.05$.

\section{Results}

The strain, LMU B01 showed its optimal keratinolytic activity and biodegrative potential at $45^{\circ} \mathrm{C}$ by the crude enzyme with $75 \pm 2.7 \mathrm{U} / \mathrm{mL}$, while the immobilised enzyme had $112 \pm 4.2 \mathrm{U} / \mathrm{mL}$ and at $48 \mathrm{~h}$ after the fermentation began, respectively, with $82 \pm 4.1 \mathrm{U} / \mathrm{mL}$ for the crude enzyme and $110 \pm 4.7 \mathrm{U} / \mathrm{mL}$ for the immobilised enzyme. The $\mathrm{pH}$ of 7 showed the optimal keratinolytic activity by the crude enzyme with $62 \pm 1.8 \mathrm{U} / \mathrm{mL}$ while the immobilised enzyme had $107 \pm 2.7 \mathrm{U} / \mathrm{mL}$ (Figure $1 \mathrm{i}$-iii).

The FI, initial weight and FCR of the birds did not differ statistically among the treatment groups as shown in Table 2. The final weight was lower for the birds on treatment groups in comparison with the control. The BWG of the birds fed immobilised enzymedegraded feather meal-based diet compared with the control and other groups.

The organ/part weights and body weight ratio of liver, visceral, wings, and gizzard did not differ significantly among the treatment groups (Table 3). Dressed weight was lower for birds on commercial feather meal-based diet when compared with the control diet, but the value obtained was statistically similar to the values obtained for birds on crude and immobilised enzymedegraded feather meal. The values obtained for enzyme-degraded feather meal and control group were similar. Head and leg weights to live body weight ratio was significantly $(\mathrm{P}<0.05)$ higher for birds on crude and immobilised enzyme-degraded feather meal-based diets in comparison with the control group. Birds on commercial feather meal-based diet had a value which was statistically similar to values obtained from the control group and crude enzyme-degraded feather meal group. The intestinal weight to body weight ratio were similar. 


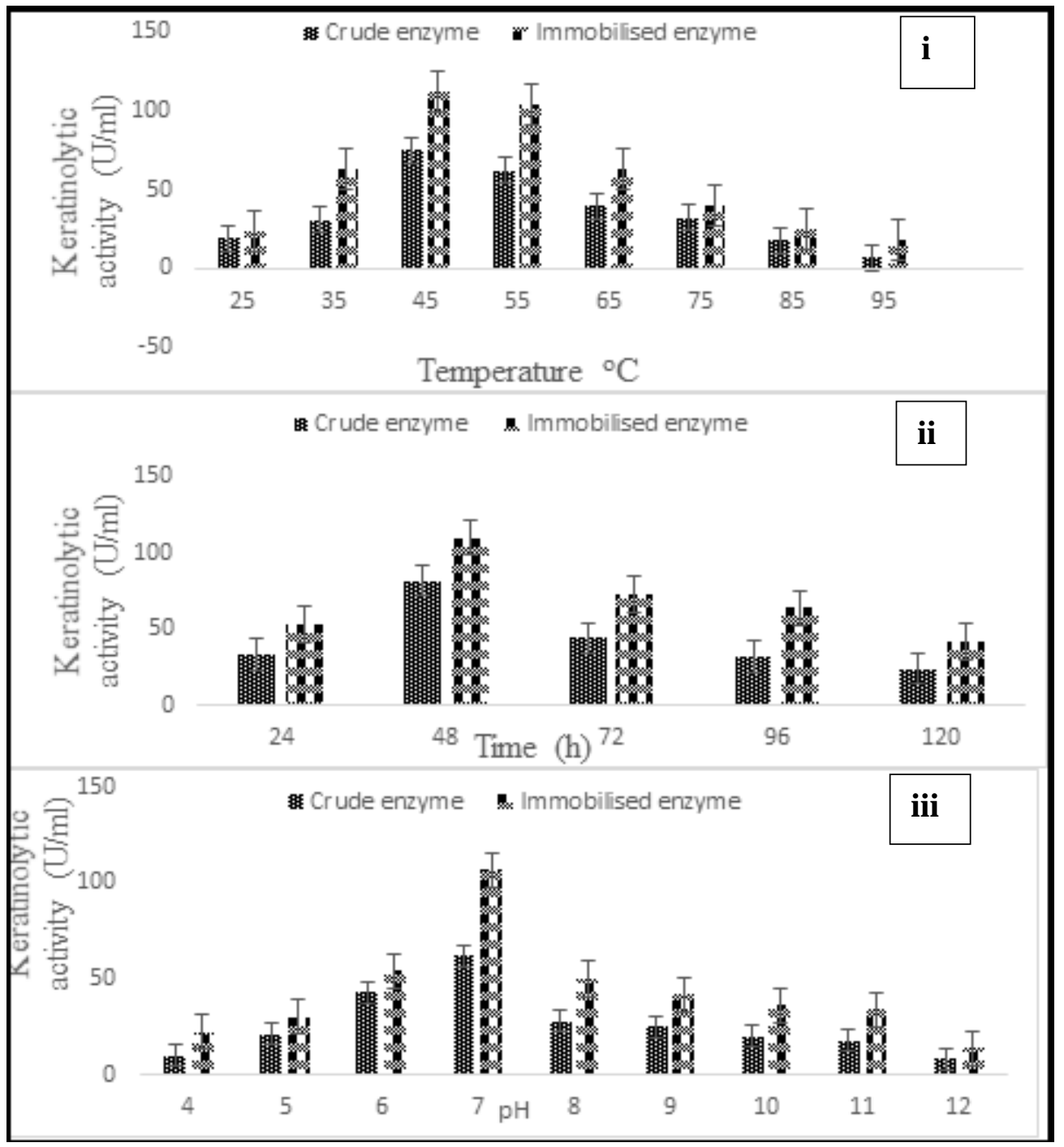

Figure 1. Effect of temperature (i), time (ii) and $\mathrm{pH}$ (iii) on keratin biodegradation on Bacillus subtilis (LMU B01).

Table 2. Growth performance parameters of broiler chickens fed feather meal-based and control diets.

\begin{tabular}{|l|c|c|c|c|c|}
\hline \multicolumn{1}{|c|}{ Parameter } & $\begin{array}{c}\text { Control } \\
\text { diet }\end{array}$ & $\begin{array}{c}\text { Commercial } \\
\text { feather } \\
\text { meal-based } \\
\text { diet }\end{array}$ & $\begin{array}{c}\text { Crude enzyme } \\
\text { degraded } \\
\text { feather meal- } \\
\text { based diet }\end{array}$ & $\begin{array}{c}\text { Immobilised } \\
\text { enzyme } \\
\text { degraded } \\
\text { feather meal- } \\
\text { based diet }\end{array}$ & P-value \\
\hline Feed intake $(\mathrm{kg})$ & $0.99 \pm 0.08^{\mathrm{ns}}$ & $0.99 \pm 0.02^{\mathrm{ns}}$ & $0.98 \pm 0.02^{\mathrm{ns}}$ & $0.97 \pm 0.01^{\mathrm{ns}}$ & 0.944 \\
\hline Initial weight $(\mathrm{kg})$ & $0.48 \pm 0.05^{\mathrm{ns}}$ & $0.46 \pm 0.06^{\mathrm{ns}}$ & $0.45 \pm 0.05^{\mathrm{ns}}$ & $0.45 \pm 0.04^{\mathrm{ns}}$ & 0.882 \\
\hline Final weight $(\mathrm{kg})$ & $1.03 \pm 0.03^{\mathrm{a}}$ & $0.93 \pm 0.04^{\mathrm{b}}$ & $0.89 \pm 0.01^{\mathrm{b}}$ & $0.95 \pm 0.04^{\mathrm{b}}$ & 0.005 \\
\hline Weight gain $(\mathrm{kg})$ & $0.55 \pm 0.02^{\mathrm{a}}$ & $0.47 \pm 0.03^{\mathrm{b}}$ & $0.44 \pm 0.01^{\mathrm{b}}$ & $0.50 \pm 0.02^{\mathrm{bb}}$ & 0.025 \\
\hline FCR & $1.81 \pm 0.23^{\mathrm{ns}}$ & $2.11 \pm 0.18^{\mathrm{ns}}$ & $2.23 \pm 0.36^{\mathrm{ns}}$ & $1.94 \pm 0.02^{\mathrm{ns}}$ & 0.162 \\
\hline
\end{tabular}

Values are means \pm standard deviation, means with different superscripts within the same row are significantly $(P<0.05)$ different, ns = non-significant, $\mathrm{FCR}=$ feed conversion ratio. 
Table 3. Organ weight to body weight ratios of broiler chickens fed feather meal-based and control diets.

\begin{tabular}{|l|c|c|c|c|c|}
\hline \multicolumn{1}{|c|}{ Parameter } & $\begin{array}{c}\text { Control } \\
\text { diet }\end{array}$ & $\begin{array}{c}\text { Commercial } \\
\text { feather } \\
\text { meal-based } \\
\text { diet }\end{array}$ & $\begin{array}{c}\text { Immobilised } \\
\text { enzyme- } \\
\text { degraded feather } \\
\text { meal- based diet }\end{array}$ & $\begin{array}{c}\text { Crude enzyme- } \\
\text { degraded feather } \\
\text { meal- based diet }\end{array}$ & P-value \\
\hline $\begin{array}{l}\text { Dressed } \\
\text { weight }\end{array}$ & $0.70 \pm 0.10^{\mathrm{a}}$ & $0.54 \pm 0.04^{\mathrm{b}}$ & $0.64 \pm 0.04^{\mathrm{ab}}$ & $0.61 \pm 0.02^{\mathrm{ab}}$ & 0.055 \\
\hline Head + legs & $0.07 \pm 0.02^{\mathrm{c}}$ & $0.81 \pm 0.01^{\mathrm{bc}}$ & $0.11 \pm 0.01^{\mathrm{a}}$ & $0.10 \pm 0.03^{\mathrm{ab}}$ & 0.014 \\
\hline Visceral & $0.15 \pm 0.05^{\mathrm{ns}}$ & $0.12 \pm 0.02^{\mathrm{ns}}$ & $0.15 \pm 0.04^{\mathrm{ns}}$ & $0.14 \pm 0.04^{\mathrm{ns}}$ & 0.708 \\
\hline Liver & $0.02 \pm 0.01^{\mathrm{ns}}$ & $0.02 \pm 0.01^{\mathrm{ns}}$ & $0.02 \pm 0.01^{\mathrm{ns}}$ & $0.03 \pm 0.01^{\mathrm{ns}}$ & 0.429 \\
\hline Intestine & $0.05 \pm 0.01^{\mathrm{ab}}$ & $0.04 \pm 0.01^{\mathrm{b}}$ & $0.06 \pm 0.03^{\mathrm{a}}$ & $0.05 \pm 0.02^{\mathrm{ab}}$ & 0.089 \\
\hline Wings & $0.07 \pm 0.01^{\mathrm{ns}}$ & $0.06 \pm 0.01^{\mathrm{ns}}$ & $0.07 \pm 0.02^{\mathrm{ns}}$ & $0.06 \pm 0.02^{\mathrm{ns}}$ & 0.651 \\
\hline Gizzard & $0.05 \pm 0.01^{\mathrm{ns}}$ & $0.04 \pm 0.01^{\mathrm{ns}}$ & $0.06 \pm 0.01^{\mathrm{ns}}$ & $0.05 \pm 0.02^{\mathrm{ns}}$ & 0.21 \\
\hline
\end{tabular}

Values are means \pm standard deviation, means with different superscripts within the same row are significantly $(P<0.05)$ different, ns = non-significant.

The packed cell volume and haemoglobin concentrations did not differ among the groups as shown in Table 4. The immobilised and crude enzyme-degraded feather meal raised the white blood cell counts of the experimental animals when compared with the control while the feather mealbased diets raised the neutrophils (Table 4). However, feather meal based-diets lowered the lymphocytes of the experimental animals.

Table 4. Haematological parameters of broiler chicks fed with feather meal-based and control diets.

\begin{tabular}{|l|c|c|c|c|c|}
\hline Parameter & $\begin{array}{c}\text { Control } \\
\text { diet }\end{array}$ & $\begin{array}{c}\text { Commercial } \\
\text { feather } \\
\text { meal-based } \\
\text { diet }\end{array}$ & $\begin{array}{c}\text { Immobilised } \\
\text { enzyme- } \\
\text { degraded feather } \\
\text { meal- based diet }\end{array}$ & $\begin{array}{c}\text { Crude enzyme- } \\
\text { degraded feather } \\
\text { meal- based diet }\end{array}$ & P-value \\
\hline PCV (\%) & $32.0 \pm 1.3^{\mathrm{ns}}$ & $30.0 \pm 2.8^{\mathrm{ns}}$ & $28.0 \pm 2.5^{\mathrm{ns}}$ & $32.0 \pm 2.0^{\mathrm{ns}}$ & 0.467 \\
\hline $\begin{array}{l}\text { WBC } \\
\left(\mathrm{x} 10^{3} \mathrm{~mm}^{3}\right)\end{array}$ & $7.4 \pm 1.2^{\mathrm{c}}$ & $3.2 \pm 0.2^{\mathrm{d}}$ & $10.4 \pm 0.2^{\mathrm{a}}$ & $8.1 \pm 0.7^{\mathrm{b}}$ & 0.001 \\
\hline $\begin{array}{l}\text { Neutrophils } \\
(\%)\end{array}$ & $28.0 \pm 1.2^{\mathrm{d}}$ & $60.0 \pm 3.5^{\mathrm{b}}$ & $70.0 \pm 2.3^{\mathrm{a}}$ & $50.0 \pm 1.7^{\mathrm{c}}$ & 0.001 \\
\hline $\begin{array}{l}\text { Lymphocytes } \\
(\%)\end{array}$ & $72.0 \pm 2.2^{\mathrm{a}}$ & $38.0 \pm 1.5^{\mathrm{c}}$ & $30.0 \pm 2.2^{\mathrm{d}}$ & $50.0 \pm 3.1^{\mathrm{b}}$ & 0.001 \\
\hline $\begin{array}{l}\text { Haemoglobin } \\
(\mathrm{mg} / \mathrm{dl})\end{array}$ & $11.4 \pm 1.1^{\mathrm{ns}}$ & $10.7 \pm 1.0^{\mathrm{ns}}$ & $10.0 \pm 1.8^{\mathrm{ns}}$ & $11.4 \pm 1.4^{\mathrm{ns}}$ & 0.467 \\
\hline
\end{tabular}

Values are means \pm standard deviation, means with different superscripts within the same row are significantly $(P<0.05)$ different, $\mathrm{ns}=$ non-significant, $\mathrm{PCV}=$ Packed Cell Volume, $\mathrm{WBC}=$ White Blood Cell counts, RBC $=$ Red Blood Cell counts. 
The photomicrographs of the control group indicated moderate infiltration of lamina propria as well as glands with inflammatory cells of the mucosal layer (a), inflammation and mild infiltration of the crypts and villi (b), and submucosal layer (c), respectively. The circular muscle layer was normal (d). For the commercial feather meal, the mucosal layer (a), villi (b), submucosal layer (c) and circular muscle layer (d) were normal. Similar observation was made for the immobilized and crude enzyme-degraded feather meal, except that the mucosal layer showed mild inflammatory cells infiltration of the glands (Figures 2 i-iv).
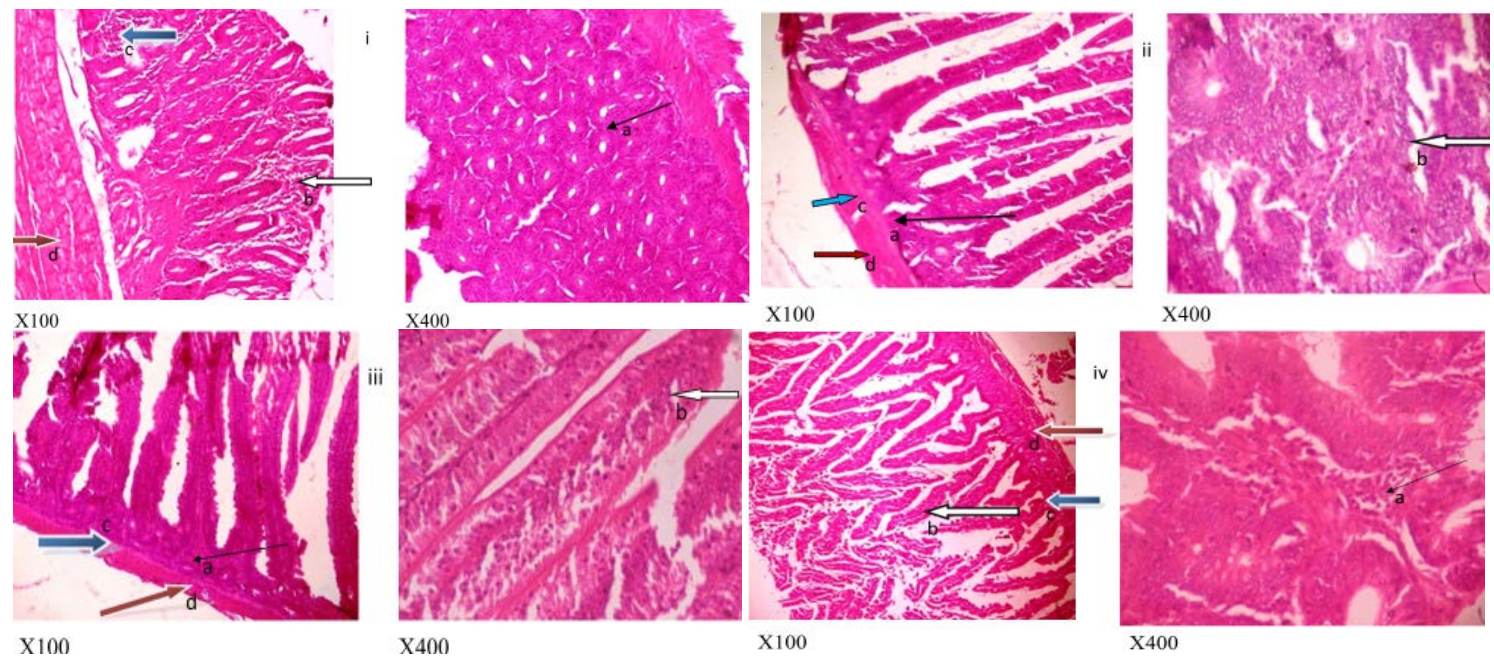

$\mathrm{X} 400$

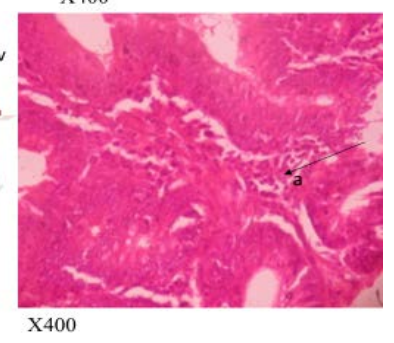

Figure 2. Intestinal photomicrographs of chickens fed the control diet (i), commercial feather meal (ii), immobilized enzyme-degraded feather meal (iii) and crude enzyme-degraded feather meal (iv).

\section{Discussion}

The FCR in the study was similar to the previous report by Ochetim (1993). The author noted that that boiled feather meal $(3 \%)$ did not differ from the control group while $4.5 \%$ inclusion level depressed FCR. However, 0\%-3\% boiled feather meal were reported to have higher carcass yields. The enzymedegraded feather meal resulted in higher head and legs to body weight ratio. However, this study focused more on the organ size than the carcass yield. It was observed that enzyme-degraded feather meal did not lead to organ inflammation or colour change in the experimental animals which is an indication that the test ingredients are safe for poultry consumption. The imbalance in amino acid profile of feather meal may be responsible for the variation in performance of broilers (Ochetim, 1993; Adejumo et al., 2016), which immobilised enzyme has helped to enhance. However, studies with longer duration may shed more light on this.

A lower body weight as well as dietary intake of keratin-based diets has been reported Grazziotin et al. (2008) but methionine supplementation to feather hydrolysate diet has been shown to enhance BWG in rats. Decreased FCR and BWG for enzyme-treated and autoclaved feather meal has also been reported (Rutkowski et al., 2003), although, the differences became negligible as the study was prolonged. Low digestibility of lysine was indicated as being responsible for the decreased 
BWG (Adejumo and Onifade, 2005). The feeding of fermented and feather meal at different rates has been observed not to affect FI, BWG and FCR of Clarias gariepinus, Heterobranchus bidorsalis and broiler chicks within the first 21st day of age (Arunlertaree and Rakyuttithamkul, 2006; Caires et al., 2010; Ejere et al., 2014).

The importance of small intestine in nutrient digestion and absorption cannot be over-emphasized. It has been designated as the nutrient digestion and nutrient absorption site, which in turn influence weight gain of the animals. Feed restriction and a reduction in feed intake have been associated with reduced intestinal villi height $\mathrm{CHu}$ and Guo, 2008). Considering the histological result of the present study it may be inferred that enzyme-degraded feather meal did not pose any threat to the nutrient digestion, absorption and function of the small intestine of the animals.

Feather meal is rich in cysteine but limited in methionine and lysine contents (Adejumo et al., 2016). Cysteine is however considered as an important amino acid when processing feather processing (Papadopoulus et al., 1985; Moritz and Latshaw, 2001). Feather meal (14 and $18 \%$ feeding rate) has been shown to reduce FI, BWG, feed efficiency, liver enzymes, increased haemoglobin and mean cell volume of rabbits (Adejumo and Onifade, 2005). An additional benefit of using feather meal in livestock feeding is the cost effectiveness. It is also promises to be a positive approach of disposing solid wastes in countries with disposal problems as well as reducing the cost of disposal of such wastes.

The result obtained from the optimization of $\mathrm{pH}$ is in line with the result obtained by Riffel et al. (2003). The temperature at which the maximum keratinase activity was observed in the present study is in line with the reports from previous findings, which is an indication that the keratinolytic strain adopted in the present study is a promising candidate for biotechnology (Gupta and Ramnani, 2006; Xu et al., 2009). The immobilised enzyme had a greater effect on the keratinolytic activities and a greater stability was observed (Arica et al., 1998).

\section{Conclusion}

Immobilised enzyme-degraded feather meal compared with the control and could better improve the performance of broiler chickens. However, further studies may be required to clarify this. The enzymedegraded feather meal is safe for inclusion in the diet of the broiler chickens and slight feeding manipulations could improve the growth performance of enzyme-degraded feather meal-based diets. In spite of the findings from this study, we recommend further studies with longer duration and amino acid supplementation in order to further establish the findings obtained in this study.

\section{Conflict of interest}

We declared that we have no conflict of interest regrading this manuscript.

\section{References}

Adejumo, D. O.; Onifade, A. A. Effects of graded levels of feather meal as a dietary protein source on growth performance, haematology, serum chemistry and clinical enzyme activities in rabbits. Asset Series A, v. 5, p. 129-138, 2005.

Adejumo, I. O.; Adetunji, C. O.; Ogundipe, K.; Osademe, S. N. Chemical composition and amino acid profile of differently processed feather meal. J. Agric. Sci., v. 61, p. 237-246, 2016. https://doi.org/10.2298/JAS1603237A

Adetunji, C. O.; Adejumo, I. O. Efficacy of crude and immobilized enzymes from Bacillus licheniformis for production of biodegraded feather meal and their 
assessment on chickens. Env. Tech. \& Inn., v. 11, p. 116-124, 2018.

Adetunji, C. 0.; Adejumo, I. O. Nutritional assessment of mycomeat produced from different agricultural substrates using wild and mutant strains from Pleurotus sajor-caju during solid state fermentation. Anim. Feed Sci. and Tech., v. 224, p. 14-19, 2017.

Adetunji, C. O.; Makanjuola, O. R.; Arowora, K. A.; Afolayan, S. S.; Adetunji, J. B. Production and Application of Keratin-Based Organic Fertilizer from Microbially Hydrolyzed Feathers to cowpea (Vigna unguiculata). Int. J. Sci. \& Eng. Res., v. 3, p. 1-9, 2012.

Aiello, S. E. The Merck Veterinary Manual. 8. ed. Whitehouse Station, USA: Merck, 1998.

Arica, M. Y.; Alaeddinoglu, N. G.; Hasirci, V. Immobilization of glucoamylase onto activated pHEMA/EGDMA microspheres: properties and application to a packed-bed reactor. Enz. Microbial. Tech., v. 22, p. 152157, 1998.

Arunlertaree, C.; Rakyuttithamkul, E. Utilization of fermented feather meal as a replacement of fish meal in the diet of hybrid Clarias catfish. Kasetsart J. (Nat. Sci.), v. 40, p. 436-448, 2006.

Avwioro, O. G. Histochemistry and tissue pathology, principle and techniques. Nigeria: Claverianum Press, 2010.

Bellaver, C. Ingredientes de origem animal destinado à fabricação de rações. Anais do Simpósio Sobre Ingredientes na Alimentação Animal Campinas, São Paulo, Brasil, 2001.

Brandelli, A. Bacterial keratinases: Useful enzymes for bioprocessing agroindustrial wastes and beyond. Food Bioprocess. Technol., v. 1, p. 105-116, 2008.

Brandelli, A.; Daroit, D. J.; Riffel, A. Biochemical features of microbial keratinases and their production and applications. Appl. Microbiol. Biotechnol., v. 85, p. 1735-1750, 2010.

Caires, C. M.; Fernandes, E. A.; Fagundes, N. S.; Carvalho, A. P.; Maciel, M. P.; Oliveira, B. R. The use of animal byproducts in broiler feeds. Use of animal co-products in broilers diets. Braz. J. Poult. Sci., v. 12, p. 41-46, 2010.

Călin, M.; Constantinescu-Aruxandei, D.; Alexandrescu, E.; Răut, I.; Doni, M. B.; Arsene,
M.-L.; Oancea, F.; Jecu, L.; Lazăr, V. Degradation of keratin substrates by keratinolytic fungi. Electronic Journal of Biotechnology, v. 28, p. 101-112, 2017. https://doi.org/10.1016/j.ejbt.2017.05.007

Chaturvedi, V.; Bhange, K.; Bhatt, R.; Verma, P. Production of keratinases using chicken feathers as substrate by a novel multifunctional strain of Pseudomonas stutzeri and its dehairing application. Biocata. Agric. Biotechnol., v. 3, p. 176-174, 2014.

Coward-Kelly, G.; Agbogbo, F. K.; Holtzapple, M. T. Lime treatment of keratinous materials for the generation of highly digestible animal feed: 2. animal hair. Bioresour. Technol., v. 97, p. 1344-1352, 2006.

Dong, Y.-Z.; Chang, W.-S.; Chen, P. T. Characterization and over expression of a novel keratinase from Bacillus polyfermenticus B4 in recombinant Bacillus subtilis. Bioresources and Bioprocessing, 4:47, 2017. https://doi.org/10.1186/s40643 $-017-0177-1$

Duncan, D. B. Multiple range and multiple $\mathrm{F}$ tests. Biometrics, v. 11, p.1-42, 1955. https://doi.org/10.2307/3001478

Ejere, V. C.; Adeniji, A. O.; Levi, C. A.; Asogwa, C. N.; Chukwuka, C. O. Evaluation of poultry feather meal as a dietary protein source for Clarias gariepinus and Heterobranchus bidorsalis Hybrid. Int. J. Sci. and Tech., v. 3, p. 203-208, 2014

Forgacs, G.; Alinezhad, S.; Mirabdollah, A.; Feuk-Lagerstedt, E.; Horvath, I. S. Biological treatment of chicken feather waste for improved biogas production. J. Environ. Sci., v. 23, p. 1747, 2001.

Franssen, M. C. R.; Peter, Steunenberg; Elinor, L. Scott; Han, Zuilhof; Johan, P.M.S. Immobilised enzymes in biorenewables production. Chem. Soc. Rev., v. 42, p. 6491, 2017.

Galighor, A. E.; Koziff, E. N. Essentials of practical microtechnique, 2. ed. New York: Lea and Febriger, 1976.

Gopinath, S. C. B.; Periasamy, A.; Lakshmipriya, T.; Tang, T. H.; Chen, Y.; Hashim,U.; Ruslinda, A. R.; Arshad, M. K. Md. Biotechnological aspects and perspective of microbial keratinase production. BioMed Research International, v. 2015, Article ID 
140726, 2015. https://doi.org/10.1155/ $2015 / 140726$

Grazziotin, A.; Pimentel, F. A.; De Jong, E. V.; Brandelli, A. Poultry feather hydrolysate as a protein source for growing rats. Braz. J. Vet. Res. Anim. Sci., v. 45, p. 61-67, 2008.

Gröhs, F. P. A.; Folmer, C. A. P.; Brandelli, A. Purification and characterization of $a$ keratinolytic protease produced by probiotic Bacillus subtilis. Biocatal. Agric. Biotechnol., v. 7, p. 102-109, 2016. https://doi.org/ 10.1016/j.bcab.2016.05.00

Gupta, R; Ramnani, P. Microbial keratinases and their prospective applications: an overview. Appl. Microbiol. Biotechnol., v. 70, p. 21-33, 2006.

Hu, X.; Guo, Y. Corticosterone administration alters small intestinal morphology and function of broiler chickens. Asian-Aust. J. Anim. Sci., v. 21, p. 1773-1778, 2008.

Huang, Q.; Peng, Y.; Li, X. Purification and characterization of an extracellular alkaline serine protease with dehairing function from Bacillus pumilus. Curr. Microbiol., v. 43, p. 169-173, 2003.

Khardenavis, A. A.; Kapley, A.; Purohit, H. J. Processing of poultry feathers by alkaline keratin hydrolyzing enzyme from Serratia sp. HPC 1383. Waste Manag., v. 29, p. 14091415, 2009.

Laba, W.; Rodziewicz, A. Keratinolytic potential of feather degrading Bacillus polymyxa and Bacillus cereus. Pol. J. Environ. Stud., v. 19, p. 371-378, 2010.

Łaba, W.; Szczekała, K. B. Keratinolytic proteases in biodegradation of pretreated feathers. Pol. J. Environ. Stud., v. 22, p. 1101-1109, 2013.

Mariotti, M. P.; Hideko, Yamanaka; Angela, Regina Araujo; Henrique, Celso T. Hydrolysis of whey lactose by immobilized bgalactosidase. Braz. Arch. Biol. Technol., v. 51, p. 1233-1240, 2008.

Metu, A. G.; Okeyika, K. O.; Maduka, O. D. Achieving sustainable food security in Nigeria: challenges and way forward. Proceeding of the 3rd International Conference on African Development Issues (CU-ICADI), p. 182-187, 2016.
Mortiz, J. S., Latshaw, J. D. Indicators of nutritional value of hydrolyzed feather meal. Poult Sci., v. 80, p. 79-86, 2001.

Ochetim, S. The effects of partial replacement of soybean meal with boiled feather meal on the performance of broiler chickens. AJAS, v. 6, p. 597-600, 1993.

Okareh, O. T.; Awe, A. O., Sridhar, M. K. C. Effect of processed feather waste as mulch on crop growth and soil fertilization. J. Agric. and Eco. Res. Int., v. 4, p. 25-35, 2015.

Papadopolous, M. C.; El-Boushy, A. R.; Roodbeen, A. E.; Ketelaars, E. H. Effects of processing time and moisture content on amino acids composition and nitrogen characteristics of feather meal. Anim. Feed Sci. Technol., v. 14, p. 279-290, 1986.

Papadopoulos, M. C. Amino acid content and protein solubility of feather meal as affected by different processing conditions. Neth. J. Agr., v. 33, p. 317-319, 1985.

Prakash, P.; Jayalakshmi, S. K.; Sceeramulu, K. Production of keratinase by free and immobilized cells of Bacillus halodurans strain PPKS-2: partial characterization and its application in feather degradation and dehairing of the goat skin. Appl. Biochem. Biotechnol., v. 160, p. 1909-1920, 2010.

Riffel, A.; Lucas, F.; Heeb, P.; Brandelli, A. Characterization of a new keratinolytic bacterium that completely degrades native feather keratin. Arch. Microbiol., v. 179, p. 258-265, 2003.

Rutkowski, A.; Józefiak, D.; Frątczak, M.; Wiąz, M. A note on the nutritional value of enzymatically hydrolyzed feather meal for broiler chickens. J. Anim. and Feed Sci., v. 12 , p. $299-305,2003$.

Schalm, O. W.; Jain, N. C.; Caroll, E. J. Veterinary haematology. 3. ed. Philadelphia: Lea and Fabiger, 1975.

Sridhar, M. K. C. UNICEF/CASSAD. Waste Management Project in Nigeria, 2001.

Verma, A.; Singh, H.; Anwar, S.; Chattopadhyay, A.; Tiwari, K. K.; Kaur, S.; et al. Microbial keratinases: industrial enzymes with waste management potential. Crit. Rev. Biotechnol., v. 37, p. 476-491, 2016. https://doi.org/10.1080/07388551.2016.11 85388 
Wang, X.; Parson, C. M. Effect of processing systems on protein quality of feather meal and hog hair meals. Poult. Sci., v. 76, p. 491496, 1997.

Xu, B.; Zhong, Q.; Tang, X.; Yang, Y.; Huang, Z. Isolation and characterization of a new keratinolytic bacterium that exhibits significant feather-degrading capability. Afr. J. Biotechnol., v. 8, p. 4590-4596, 2009.

License information: This is an open-access article distributed under the terms of the Creative Commons Attribution License, which permits unrestricted use, distribution, and reproduction in any medium, provided the original work is properly cited. 